\title{
Hearing Loss in the Elderly: Is the Hearing Handicap Inventory for the Elderly - Screening Version Effective in Diagnosis When Compared to the Audiometric Test?
}

\author{
Alexandre Barbosa Servidoni ${ }^{1}$ Lucieni de Oliveira Conterno ${ }^{2}$ \\ ${ }^{1}$ Otorhinolaryngologist, Faculdade de Medicina de Marília (Famema), \\ SP, Brazil \\ 2 Infectologist \& Clinical Epidemiologist, Faculdade de Medicina de \\ Marília (Famema), SP, Brazil \\ Address for correspondence Alexandre Barbosa Servidoni, MD, MSc, \\ Rua José Bonifácio, 1185, 64-D, Jardim Cristo Rei, Marília-SP, 17513- \\ 230, Brazil (e-mail: absmed@hotmail.com; \\ alexandreservidoni@gmail.com).
}

Int Arch Otorhinolaryngol 2018;22:1-8.

\begin{abstract}
Introduction Hearing losses inherent to the natural process of aging represent today a major public health issue, despite the little attention that their adequate care still receives. Early recognition and proper management of these shortcomings can significantly improve hearing, as well as the patient's general quality of life, reducing the overall impact of this important and prevalent condition of the aging process.

Objective The aim of this research was to evaluate the accuracy of the Hearing Handicap Inventory for the Elderly - Screening Version (HHIE-S) in the diagnosis of hearing loss in the elderly when compared with the audiometric test.

Methods Through a cross-sectional study, our target population was composed of 138 individuals, aged over 60 and with any otorhinolaryngological complaints, recruited at the Clinic of Otorhinolaryngology and Speech Therapy of the Faculdade de Medicina de Marília (Famema), in the city of Marília, SP, Brazil. Patients already in the process of auditory rehabilitation were excluded, as well as those who did not

Keywords

- hearing loss

- presbycusis

- surveys and questionnaires

- audiometry

- aged

- aging demonstrate the minimum level of oral understanding necessary to allow the interview.

Results The prevalence of hearing loss according to the questionnaire was of $76.1 \%$, while audiometry showed $79.7 \%$. We found the diagnostic accuracy of the instrument to be of $86.2 \%$, with a sensitivity of $89.1 \%$ and a specificity of $75.0 \%$, regardless of gender.

Conclusion Thereby, we conclude that the standardized questionnaire under rating is suitable for the screening of hearing loss in the elderly, given its high accuracy and userfriendly quality.
\end{abstract}

\section{Introduction}

The hearing losses inherent to the natural process of aging represent a major public health issue, despite the little attention that they receive regarding their proper management. ${ }^{1-10}$

received

September 21, 2016

accepted after revision

January 2, 2017

published online

March 31, 2017
DOI https://doi.org/

10.1055/s-0037-1601427. ISSN 1809-9777.
The test considered the gold standard for evaluating the auditory function is the pure tone audiometry (PTA), which does not consider the loss qualitatively, but classifies the extent of the loss at different frequencies tested. ${ }^{11-17}$ There is still no consensus on the most appropriate classification of
Copyright $(2018$ by Thieme Revinter

Publicações Ltda, Rio de Janeiro, Brazil
License terms

(c) (i) $\ominus$ (\$) 
hearing loss regarding the degree of intensity, which is obtained from the arithmetic average of the hearing thresholds found in the different frequencies tested. ${ }^{18-26}$

Hearing impairment refers to any restriction or lack of ability to perceive sound and to perform tasks due to hearing problems experienced by those affected by hypoacusis. On the other hand, hearing handicap refers to the emotional and social aspects resulting from hearing impairment, which can sometimes restrict the individual's participation in everyday activities, as well as impact family relationships and social interactions. ${ }^{27-29}$

In 1982 , Ventry and Weinstein ${ }^{30}$ developed in the United States the Hearing Handicap Inventory for the Elderly (HHIE), a self-assessment tool containing 25 questions aimed to assess the impact of hearing loss in the emotional and social-situational adjustments of elderly patients who are not institutionalized. ${ }^{31-36}$ In 1983, the same authors published a reduced version of the HHIE containing only 10 questions, but also divided between social and emotional aspects: the Hearing Handicap Inventory for the Elderly Screening Version (HHIE-S), proposed as a screening tool to detect the degree of hearing complaints. ${ }^{34,37-39}$

In 1997 , Wieselberg ${ }^{40}$ released the pioneering work of translation and adaptation of the HHIE into the Portuguese language. And according to Paiva et $\mathrm{al}^{41}{ }^{4}$ the translation into Portuguese maintained the validity of the English version.

In view of the relevance of the subject due to the high prevalence of hearing disorders and their harmful consequences; ${ }^{42}$ and considering that there are more simple and inexpensive tools for tracking them, we aimed to assess the accuracy of the HHIE-S in the diagnosis of hearing losses in the elderly when compared with PTA; besides, the sensitivity and specificity of the instrument were defined, and the prevalence of hearing disorder in the target population was determined both by the questionnaire and by PTA.

\section{Methods}

A cross-sectional study with a quantitative approach was conducted to evaluate the accuracy of the HHIE-S questionnaire as a diagnostic test when compared with PTA, which is considered the gold standard for detecting hearing loss.

The target population of this study consisted of elderly individuals aged over 60 years, who were patients at the Clinic of Otorhinolaryngology and Speech Pathology of Faculdade de Medicina de Marília (Famema), in the city of Marília, SP, Brazil. The individuals included in the study were previously scheduled or referenced in for elective outpatient consultations in the morning, Monday to Friday, thus fulfilling the requirement of being able to present an otorhinolaryngologic complaint. As the location is not a specific hearing loss clinic, individuals scheduled randomly throughout the week did not necessarily have hearing complaints.

Users of hearing aids or patients already in the process of audiological rehabilitation were excluded, as well as those who did not demonstrate a minimum level of listening to allow the questionnaire; ${ }^{43-46}$ individuals with active infec- tious diseases or tumors diagnosed during the otoscopy were also excluded and referred to proper treatment.

The sample size $(\mathrm{N})$ was calculated taking into account previous literature data evaluating the performance of the HHIE-S questionnaire in a population without known hearing disorders. ${ }^{23,25,47}$ Thereby, the final $\mathrm{N}=138$ was achieved.

Data collection only started after the patients read and signed the consent form, thus allowing the use of the data obtained in accordance with the standards set by the Ethics Committee of our Academic Institute. Therefore, the execution of this research was duly approved by the Ethics Committee of the institution, through protocol number 950,987, released on February 10, 2015.

After routine otoscopy, all participants were initially submitted to the HHIE-S questionnaire, aimed at analyzing the perception of hearing handicap. ${ }^{34,37,48-51}$ This questionnaire was always applied by the same researcher, and the items read orally by the interviewer and immediately answered by the interviewee, a technique known as face to face. Individuals responded to questions related to hearing skills, indicating when a situation represented a problem..$^{32,52-54}$ If requested by the patient, a brief explanation or a new reading was provided. The average time for the whole questionnaire ranged between 5 and 10 minutes, depending on the ability of each interviewee.

After the interview with the HHIE-S questionnaire, the individual was then referred for further examination by PTA, performed by the speech therapists from our clinic, preferably and mostly on the same day as the initial interview; when this was not possible due to logistical or time constraint reasons, the PTA examination was scheduled as a routine service, to be performed within a maximum period of two months. On the day set for the audiometric examination, a new otoscopy was performed initially, but repetition of the HHIE-S was not necessary. ${ }^{34,37,55-58}$ For this research, we used the audiometer 229E Interacoustics model (Middelfart, Denmark), set to the proper calibrations, as well as an appropriate acoustic booth.

To include a wider range of frequencies that encompass both the energy of speech sounds and their inteligibility, 59 we adopted the classification proposed by the World Health Organization (WHO), ${ }^{60}$ which uses the arithmetic mean of the hearing thresholds at $500 \mathrm{~Hz}, 1,000 \mathrm{~Hz}, 2,000 \mathrm{~Hz}$ and $4,000 \mathrm{~Hz}$, as well as $25 \mathrm{~dB} \mathrm{HL}$ as normality threshold. It is important to note that the frequency of $4,000 \mathrm{~Hz}$ is among the first to demonstrate an age-related decline, and is, therefore, fundamental in understanding speech, especially in noisy environments. ${ }^{19,57,61}$ The classification adopted was made as shown in - Table 1: ${ }^{60}$

The accuracy of the HHIE-S questionnaire was determined by calculating the sensitivity and specificity, comparing the results that were true positive, false positive, true negative and false negative with the PTA. The confidence intervals (CIs) used to estimate the sensitivity, specificity, positive predictive value and negative predictive value were calculated using the exact method of Clopper-Pearson. ${ }^{62,63}$ Analyses were performed using the IBM statistics software SPSS 17.0 (North Castle, NY, USA). 
Table 1 Audiological classification adopted (WHO)

\begin{tabular}{|l|l|}
\hline Normal hearing & $0-25 \mathrm{~dB} \mathrm{HL}$ \\
\hline Mild hearing loss & $26-40 \mathrm{~dB} \mathrm{HL}$ \\
\hline Moderate hearing loss & $41-60 \mathrm{~dB} \mathrm{HL}$ \\
\hline Severe hearing loss & $61-80 \mathrm{~dB} \mathrm{HL}$ \\
\hline Profound hearing loss & $\geq 81 \mathrm{~dB} \mathrm{HL}$ \\
\hline
\end{tabular}

Abbreviations: $\mathrm{dB} \mathrm{HL}$, decibels hearing level; WHO, World Health Organization.

\section{Results}

The demographic and epidemiological data obtained in this study are summarized and presented in -Table 2.

The evaluation by the HHIE-S showed that 33 elderly patients (23.9\%) had no perception of hearing handicap; 65 (47.1\%) had mild/moderate perception of handicap; and 40 (29.0\%) had a significant perception of handicap. Thus, the prevalence of hearing impairment by the HHIE-S questionnaire, considering the absence or presence of any perception of hearing handicap, was of $76.1 \%$ (105/138). The prevalence data as classified by the HHIE-S are described in - Table 3 (irrespective of sex) and - Table 4 (comparing sexes).

Table 2 Clinical and epidemiological characteristics of 138 elderly patients evaluated at the Clinic of Otorhinolaryngology and Speech Therapy of Famema

\begin{tabular}{|l|l|l|}
\hline & Number of patients & Percentage \\
\hline & Total & $\%$ \\
\hline Male & 138 & $100 \%$ \\
\hline Female & 71 & $51.4 \%$ \\
\hline Average age \pm SD & $71.6 \pm 8.1$ & $48.6 \%$ \\
\hline $60-70$ years old & 71 & - \\
\hline $71-80$ years old & 45 & $51.4 \%$ \\
\hline$>80$ years old & 22 & $32.6 \%$ \\
\hline Schooling & \multicolumn{2}{|l|}{} \\
\hline Elementary School & 34 & $15.9 \%$ \\
\hline Middle School & 93 & $67.4 \%$ \\
\hline High School & 06 & $4.3 \%$ \\
\hline Higher Education & 05 & $3.6 \%$ \\
\hline Diseases & \multicolumn{2}{|l|}{} \\
\hline Diabetes mellitus & 30 & $21.7 \%$ \\
\hline Hypertension & 89 & $64.5 \%$ \\
\hline Dyslipidemia & 23 & $16.7 \%$ \\
\hline Thyroid disease & 17 & $12.3 \%$ \\
\hline Otologic disease & 15 & $10.9 \%$ \\
\hline Other diseases & 68 & $49.3 \%$ \\
\hline
\end{tabular}

Abbreviation: SD, standard deviation.

Note: * Individuals may have more than one associated disease.
Table 3 Hearing disorder prevalence according to the HHIE-S, irrespective of sex, for 138 elderly patients evaluated the Clinic of Otorhinolaryngology and Speech Therapy of Famema

\begin{tabular}{|l|l|l|}
\hline Handicap & \multicolumn{2}{|l|}{ Elderly population studied } \\
\hline & Number of patients & Percentage \\
\hline & TOTAL (138) & $\%(100 \%)$ \\
\hline Absence & 33 & $23.9 \%$ \\
\hline Mild/Moderate & 65 & $47.1 \%$ \\
\hline Severe & 40 & $29.0 \%$ \\
\hline Any handicap & 105 & $76.1 \%$ \\
\hline
\end{tabular}

Abbreviation: HHIE-S, Hearing Handicap Inventory For The Elderly Screening Version.

The audiometric evaluation of these patients, considering the overall PTA, showed the following proportions: normal hearing in 28 subjects (20.3\%); mild hearing loss in 39 (28.3\%); moderate hearing loss in 53 (38.4\%); severe hearing loss in 13 (9.4\%); and profound hearing loss in 5 subjects (3.6\%). The prevalence of hearing impairment by audiometric testing, considering the overall result and including all its degrees of intensity, was of 79.7\% (110/138).

- Table 5 shows the prevalence data of hearing impairment according to PTA and its intensity levels, separated by right and left ear and globally.

Comparing the results obtained from the HHIE-S questionnaire and the overall PTA, we observed that among the 28 individuals with normal hearing by audiometric examination, 21 (75.0\%) revealed no handicap, that is, had no perception of hearing handicap. At the other end of the results, among the five individuals with profound hearing loss according to the audiometric examination, four (80.0\%) showed a severe handicap, that is, had a significant perception of hearing handicap.

In relation to the moderate hearing losses, we note that among the 53 individuals with such intensity level of hearing loss by audiometric examination, 26 (49.1\%) showed a severe

Table 4 Hearing disorder prevalence according to the HHIE-S, comparing sexes, for 138 elderly patients evaluated at the Clinic of Otorhinolaryngology and Speech Therapy of Famema

\begin{tabular}{|l|l|l|l|l|}
\hline Handicap & \multicolumn{3}{l|}{$\begin{array}{l}\text { Elderly population studied } \\
(N=138)\end{array}$} \\
\hline & \multicolumn{3}{l}{$\begin{array}{l}\text { Number of } \\
\text { patients }\end{array}$} & \multicolumn{2}{l|}{ Percentage } \\
\hline & + & $\sigma^{\pi}$ & \% & $\sigma^{\pi}$ \\
\hline Absence & 18 & 15 & $26.9 \%$ & $21.1 \%$ \\
\hline Mild/Moderate & 31 & 34 & $46.3 \%$ & $47.9 \%$ \\
\hline Severe & 18 & 22 & $26.9 \%$ & $31.0 \%$ \\
\hline Any handicap & 49 & 56 & $73.1 \%$ & $78.9 \%$ \\
\hline
\end{tabular}

Abbreviations: HHIE-S, Hearing Handicap Inventory for the Elderly Screening Version; N, number of patients.

Notes: ㅇ, female; $\sigma^{\star}$, male. 
4 Hearing Loss in the Elderly Servidoni, Conterno

Table 5 Hearing disorder prevalence according to PTA and its intensity levels, divided by ear (right and left) and overall, for 138 elderly patients evaluated at the Clinic of Otorhinolaryngology and Speech Therapy of Famema

\begin{tabular}{|l|l|l|l|l|l|l|}
\hline Hearing level $(\mathrm{WHO})$ & Right ear & \multicolumn{2}{l|}{ Left ear } & Overall \\
\hline & $\mathbf{N}$ & $\%$ & $\mathbf{N}$ & $\%$ & $\mathbf{N}$ & $\%$ \\
\hline Normal $(0-25 \mathrm{~dB})$ & 24 & $17.4 \%$ & 19 & $13.8 \%$ & 28 & $20.3 \%$ \\
\hline Mild hearing loss $(26-40 \mathrm{~dB})$ & 36 & $26.1 \%$ & 37 & $26.8 \%$ & 39 & $28.3 \%$ \\
\hline Moderate hearing loss $(41-60 \mathrm{~dB})$ & 51 & $37.0 \%$ & 45 & $32.6 \%$ & 53 & $38.4 \%$ \\
\hline Severe hearing loss $(61-80 \mathrm{~dB})$ & 20 & $14.5 \%$ & 24 & $17.4 \%$ & 13 & $9.4 \%$ \\
\hline Profound hearing loss $(\geq 81 \mathrm{~dB})$ & 07 & $5.1 \%$ & 13 & $9.4 \%$ & 05 & $3.6 \%$ \\
\hline
\end{tabular}

Abbreviations: $\mathrm{dB}$, decibels; N, number of patients; PTA, pure tone audiometry; WHO, World Health Organization.

handicap, another 26 (49.1\%) showed a mild to moderate handicap, and only 1 (1.9\%) revealed no handicap.

The results found in the comparison between both diagnostic methods (HHIE-S and PTA) are shown in - Table 6.

When comparing the overall results of HHIE-S and PTA, irrespective of the intensity levels, that is, simply considering the handicap as absent or present and the audiometric test as normal or abnormal, we found the following results: among the 28 individuals with normal audiometric examinations, 21 (75.0\%) showed no handicap, and only 7 (25.0\%) showed some perception of hearing handicap. Among the 110 individuals with abnormal audiometric examinations, 98 (89.1\%) revealed the presence of some degree of handicap, while only $12(10.9 \%)$ had no perception of any hearing handicap.

- Table 7 shows the comparison of the overall results of the two diagnostic methods (HHIE-S and PTA) without taking into account the degrees of intensity.

From the previous table (-Table 7 ), we calculated the sensitivity, specificity, and positive and negative predictive values, with their CIs, and the accuracy of the HHIE-S questionnaire compared with the gold standard PTA, considering the overall assessment.

- Table 8 describes the statistical data of the HHIE-S, showing their calculations and the final results.
When comparing sexes, we calculated the prevalence of hearing impairment according to three criteria: the PTA, the HHIE-S questionnaire, and both methods together.

Thus, according to the overall audiometric examination and considering all the intensity levels, the prevalence of hearing impairment was of $73.1 \%$ (49/67) among women, and of $85.9 \%$ (61/71) among men.

According to the HHIE-S, and considering any level of handicap, the prevalence of hearing impairment was also of $73.1 \%$ (49/67) among women, and of 78.9\% (56/71) among men.

And considering both methods together (PTA and HHIE-S), we found a prevalence of 68.7\% (46/67) among women, and of 73.2\% (52/71) among men.

When we evaluated the sensitivity, specificity and positive and negative predictive values, and their CIs, again considering the two methods together, but now comparing the sexes, we observed that all results were higher for females.

Thus, women showed a sensitivity of 93.9\% (46/49), a specificity of $83.3 \%$ (15/18), a positive predictive value of $93.9 \%$ (46/49) and a negative predictive value of $83.3 \%$ (15/ 18). Among men, we found a sensitivity of $85.3 \%$ (52/61), a specificity of $60.0 \%(6 / 10)$, a positive predictive value of $92.9 \%$ $(52 / 56)$ and a negative predictive value of $40.0 \%$ (6/15).

- Table 9 displays the statistical results obtained and described before.

Table 6 Relationship between the results of the HHIE-S and the PTA, according to intensity levels, for 138 elderly patients evaluated at the Clinic of Otorhinolaryngology and Speech Therapy of Famema

\begin{tabular}{|l|l|l|l|l|l|l|}
\hline & \multicolumn{6}{|l|}{ PTA } \\
& $\begin{array}{l}\text { Normal } \\
\text { hearing }\end{array}$ & $\begin{array}{l}\text { Mild hearing } \\
\text { loss }\end{array}$ & $\begin{array}{l}\text { Moderate } \\
\text { hearing loss }\end{array}$ & $\begin{array}{l}\text { Severe } \\
\text { hearing loss }\end{array}$ & $\begin{array}{l}\text { Profound } \\
\text { hearing loss }\end{array}$ & Total \\
\hline & $\mathbf{N}(\%)$ & $\mathbf{N}(\%)$ & N (\%) & N (\%) & N (\%) & N (\%) \\
\hline HHIE-S & & & & & & \\
\hline Absence of handicap & $21(75.0 \%)$ & $11(28.2 \%)$ & $01(1.9 \%)$ & $0(0.0 \%)$ & $0(0.0 \%)$ & $33(23.9 \%)$ \\
\hline Mild/Moderate handicap & $06(21.4 \%)$ & $26(66.7 \%)$ & $26(49.1 \%)$ & $06(46.2 \%)$ & $01(20.0 \%)$ & $65(47.1 \%)$ \\
\hline Severe handicap & $01(3.6 \%)$ & $02(5.1 \%)$ & $26(49.1 \%)$ & $07(53.8 \%)$ & $04(80.0 \%)$ & $40(29.0 \%)$ \\
\hline Total & $28(100 \%)$ & $39(100 \%)$ & $53(100 \%)$ & $13(100 \%)$ & $05(100 \%)$ & $138(100 \%)$ \\
\hline
\end{tabular}

Abbreviation: HHIE-S, Hearing Handicap Inventory For The Elderly - Screening Version; N, number of patients; PTA, pure tone audiometry. Note: \%, percentage (regarding the PTA). 
Table 7 Comparison between the overall results of the HHIE-S and the PTA, irrespective of the intensity levels, for 138 elderly patients evaluated at the Clinic of Otorhinolaryngology and Speech Therapy of Famema

\begin{tabular}{|l|l|l|l|}
\hline \multicolumn{2}{|l|}{ PTA } & Total \\
\hline & Normal & Abnormal & \\
\hline Handicap & & & \\
\hline Absent & $21(75.0 \%)$ & $12(10.9 \%)$ & $33(23.9 \%)$ \\
\hline Present & $07(25.0 \%)$ & $98(89.1 \%)$ & $105(76.1 \%)$ \\
\hline Total & $28(100.0 \%)$ & $110(100.0 \%)$ & $138(100.0 \%)$ \\
\hline
\end{tabular}

Abbreviations: HHIE-S, Hearing Handicap Inventory For The Elderly Screening Version; PTA, pure tone audiometry.

\section{Discussion}

Considering only the HHIE-S questionnaire, we observed that $23.9 \%$ of the subjects did not perceive a handicap, while $76.1 \%$ reported the perception of some level of handicap (mild/ moderate or significant); comparing sexes, we observed perception in $73.1 \%$ of women and $78.9 \%$ of men. Cruickshanks et $\mathrm{al}^{16}$ found $33.7 \%$ with hearing handicap, considering both sexes; Wieselberg ${ }^{40}$ observed $91.0 \%$ among women and $86.0 \%$ among men; Sestrem ${ }^{64}$ found $58.0 \%$ among women and $43.0 \%$ among men. After reviewing the literature, we found no other studies reporting the prevalence of hearing impairment determined by HHIE-S alone, so that we could make a broader comparative analysis.

It is difficult to compare data on the prevalence of hearing loss among the various published studies, due to differences in sampling, populations and scenarios, as well as due to lack of consensus on audiometric criteria and/or different questionnaires used. ${ }^{65-68}$

Table 8 Statistics of the HHIE-S, compared with the overall PTA, for 138 elderly patients evaluated at the Clinic of Otorhinolaryngology and Speech Therapy of Famema

\begin{tabular}{|l|l|l|l|}
\hline & Calculus & Results & $95 \% \mathrm{Cl}$ \\
\hline Accuracy & $(21+98) / 138$ & $86.2 \%$ & $79.4-91.0$ \\
\hline Sensitivity & $98 / 110$ & $89.1 \%$ & $81.7-94.2$ \\
\hline Specificity & $21 / 28$ & $75.0 \%$ & $55.1-89.3$ \\
\hline $\begin{array}{l}\text { Positive } \\
\text { predictive } \\
\text { value }\end{array}$ & $98 / 105$ & $93.3 \%$ & $86.8-97.3$ \\
\hline $\begin{array}{l}\text { Negative } \\
\text { predictive } \\
\text { value }\end{array}$ & $21 / 33$ & $63.6 \%$ & $45.1-79.6$ \\
\hline Positive LR & Sen/1-Spe & 3.56 & $1.87-6.79$ \\
\hline Negative LR & $1-$ Sen/Spe & 0.15 & $0.08-0.26$ \\
\hline
\end{tabular}

Abbreviations: $\mathrm{Cl}$, confidence interval; HHIE-S, Hearing Handicap Inventory For The Elderly - Screening Version; LR, likelihood ratio; PTA, pure tone audiometry; Sen, sensitivity; Spe, specificity.
Table 9 Statistics of the HHIE-S, compared with the overall PTA and comparing sexes, for 138 elderly patients evaluated at the Clinic of Otorhinolaryngology and Speech Therapy of Famema

\begin{tabular}{|c|c|c|c|c|}
\hline & Results & 95\% Cl (우) & Results & $95 \% \mathrm{Cl}\left(0^{\top}\right)$ \\
\hline Accuracy & $91.0 \%$ & $84.2-97.9$ & $81.7 \%$ & $72.7-90.7$ \\
\hline Sensitivity & $93.9 \%$ & $82.1-98.4$ & $85.2 \%$ & $73.3-92.6$ \\
\hline Specificity & $83.3 \%$ & $57.7-95.6$ & $60.0 \%$ & $27.4-86.3$ \\
\hline $\begin{array}{l}\text { Positive } \\
\text { predictive } \\
\text { value }\end{array}$ & $93.9 \%$ & $82.1-98.4$ & $92.9 \%$ & $81.9-97.7$ \\
\hline $\begin{array}{l}\text { Negative } \\
\text { predictive } \\
\text { value }\end{array}$ & $83.3 \%$ & $57.7-95.6$ & $40.0 \%$ & $17.5-67.1$ \\
\hline $\begin{array}{l}\text { Positive } \\
\text { LR }\end{array}$ & 5.63 & $1.99-15.86$ & 2.13 & $0.99-4.59$ \\
\hline $\begin{array}{l}\text { Negative } \\
\text { LR }\end{array}$ & 0.07 & $0.02-0.22$ & 0.25 & $0.12-0.51$ \\
\hline
\end{tabular}

Abbreviations: $\mathrm{Cl}$, confidence interval; HHIE-S, Hearing Handicap Inventory For The Elderly - Screening Version; LR, likelihood ratio; PTA, pure tone audiometry.

Notes: + , female; $\sigma^{x}$, male.

Considering the overall result of the PTA and including all its degrees of intensity, according to the audiometric classification of the WHO, ${ }^{19,57,60}$ we observed a high prevalence of hearing loss: $79.7 \%$. The less serious hearing losses were the most frequently observed, with $28.3 \%$ of the subjects with mild hearing loss and $38.4 \%$ with moderate hearing loss; the more disabling hearing losses were observed to a lesser extent, with $9.4 \%$ of the subjects showing severe hearing loss, and $3.6 \%$ a profound hearing loss.

Despite the difficulty in comparing prevalence data, we note singular differences between our research and the studies reviewed. Cruickshanks et al, ${ }^{16}$ in a study published in 1998 , found an overall prevalence of hearing impairment of $45.9 \%$; Calais, ${ }^{15}$ in 2005 , found a prevalence of $12 \%$ in the age group of $45-64$ years, rising to $24 \%$ in the $65-74$ years age group, and reaching $39 \%$ at ages over 75 years; and finally, Sousa et al, ${ }^{13}$ in 2009 , observed an overall prevalence of $36.1 \%$.

In our study, we found high values in the HHIE-S accuracy (86.2\%), sensitivity (89.1\%), specificity (75.0\%) and positive predictive value (93.3\%), whereas only the negative predictive value (63.6\%) showed a lower percentage. Rosis et $\mathrm{al}^{25}$ published in 2009 a study on the accuracy of the HHIE-S in two different scenarios at Universidade Federal de São Paulo: at the Audiology Clinic, with 55 elderly subjects ( $\geq 60$ years) presenting hearing complaints, and at the Geriatrics Clinic, with 23 elderly subjects ( $\geq 60$ years) with some complaints. In the first scenario, they found an accuracy of $58.2 \%$, a sensitivity of $23.5 \%$, a specificity of $73.7 \%$, a positive predictive value of $28.6 \%$, and a negative predictive value of $68.3 \%$. In the second scenario, they found an accuracy of $91.3 \%$, a sensitivity of $94.7 \%$, a specificity of $75.0 \%$, a positive predictive value of $94.7 \%$, and a negative predictive value of $75.0 \%$. Thereby, in the group without mandatory hearing complaints (Geriatrics Clinic) there was a statistical association between the results 
obtained from the HHIE-S and the possibility of a hearing disorder. Therefore, only the Geriatrics Clinic has provided results similar to ours. It is important to emphasize that the participants in our research, despite being cared for at a specialized clinic (the Clinic of Otorhinolaryngology and Speech Therapy of Famema), might have otorhinolaryngologic complaints that are not just hearing-related. The previous data also seem to agree with the study of Menegotto et al, ${ }^{20}$ published in 2011. This study concluded that, at least at audiology clinics, a scenario in which all patients necessarily have hearing complaints, the questionnaires have not proved to be effective tools for hearing screening. In a sample of 51 adults and elderly subjects, they obtained a low sensitivity (47\%) and a high specificity (75\%); for this, they used the HHIE$\mathrm{S}$ questionnaire for the elderly, as well as its equivalent for adults, the Hearing Handicap Inventory for the Adults - Screening Version (HHIA-S), ${ }^{69,70}$ both later compared with the audiometric examination. Thus, we believe that the questionnaires could be valid in health services not specific to audiology, such as a general clinic of otorhinolaryngology, geriatrics or even primary care. However, further studies are needed to confirm this hypothesis.

Evaluating the results found in our current research, we noticed a greater agreement on the extremes, that is, between individuals with normal hearing and absent handicap (75.0\%), and between those with profound hearing loss and severe handicap (80.0\%). For this reason, our data suggest that the HHIE-S is more suitable to identify more disabling hearing losses (severe and profound), just as Deepthi and Kasthuri ${ }^{71}$ observed in 2012, and to identify with good reliability the absence of hearing disorder.

Among the 110 subjects with abnormal audiometry, 98 (89.1\%) showed some degree of perceived handicap, while only 12 (10.9\%) showed no perception of hearing handicap. And among 28 individuals with normal hearing, 21 (75.0\%) had not perceived handicap, while only 7 (25.0\%) showed some degree of perception of hearing handicap.

From the above discussion, we can see that the PTA alone is insufficient to describe the reaction of the individual before a hearing disorder, that is, it does not detect the hearing handicap. At the same time, the HHIE-S alone is not always able to accurately detect auditory sensitivity.

According to several authors, ${ }^{31,65-68}$ despite the high prevalence of hearing disorders in the elderly, such an indepth investigation is still generally restricted to medical evaluations. For this reason, they suggest the hearing screening as a useful tool in primary care, using a standardized questionnaire, such as the HHIE-S. ${ }^{72,73}$

\section{Conclusion}

From the results obtained in this study, we conclude that the instrument under evaluation, the HHIE-S questionnaire, is suitable in the screening for hearing loss in the elderly, given its high accuracy and user-friendly quality.

Considering the methods used and the results obtained, we also conclude that there is $10.9 \%$ of probability that the elderly with no handicap show a hearing loss, as well as $89.1 \%$ of probability that some degree of hearing loss exists in the elderly with a hearing handicap.

Moreover, it is a simple and inexpensive tool, requiring little time for its application, 10 minutes at most, and thus, it can be incorporated into traditional clinical care.

We must keep in mind that no patient should be in a process of rehabilitation without both instruments, the PTA and the HHIE-S, complementing each other.

Besides extending this research to other settings, we believe that the future association of a qualitative research might clarify some yet unknown relevant aspects, such as the possible attitudes and meanings that the elderly take on when undergoing a hearing care interview, which are likely to influence the final results.

We thus hope that such issues may be useful for all health professionals who are interested in furthering such an important subject, which concerns all of us who seek a healthy and humanized aging process.

\section{References}

1 Bogardus ST Jr, Yueh B, Shekelle PG. Screening and management of adult hearing loss in primary care: clinical applications. JAMA 2003;289(15):1986-1990

2 Weinstein BE. Evaluation and management of the hearing-impaired elderly. Geriatrics 1990;45(02):75-83, 79-80, 83

3 IBGE. Censo 2010 [Internet]. Rio de Janeiro(RJ): IBGE; 2016 [citado em 5 maio 2016]. Disponível em: http://censo2010.ibge.gov.br/ resultados

4 Pinzan-Faria VM, Iorio MCM. Sensibilidade auditiva e autopercepção do handicap: um estudo em idosos. Distúrb Comun 2004; 16(03):289-299

5 Gates GA, Murphy M, Rees TS, Fraher A. Screening for handicapping hearing loss in the elderly. J Fam Pract 2003;52(01):56-62

6 do Carmo LC, Médicis da Silveira JA, Marone SA, D'Ottaviano FG, Zagati LL, Dias von Söhsten Lins E. Audiological study of an elderly Brazilian population. Rev Bras Otorrinolaringol 2008;74(03): 342-349

7 Alvarenga KF, Bevilacqua MC, Martinez MANS, Melo TM, Blasca WQ Taga MFL. Proposta para capacitação de agentes comunitários de saúde em saúde auditiva. Pró-Fono R Atual Cient 2008; 20(03):171-6

8 Bramatti L, Morata TC, Marques JM. Ações educativas com enfoque positivo em programa de conservação auditiva e sua avaliação. Rev CEFAC 2008;10(03):398-408

9 Karlsmose B, Lauritzen T, Engberg M, Parving A. A randomised controlled trial of screening for adult hearing loss during preventive health checks. Br J Gen Pract 2001;51(466):351-355

10 Gândara MER, Alves FRA. Presbiacusia. Neto SC, Mello JF Jr, Martins RHG, Costa SS. Tratado de Otorrinolaringologia e Cirurgia Cervicofacial. Volume II Otologia-Otoneurologia. $2^{\mathfrak{a}}$ ed. São Paulo (SP): Roca; 2011:302-13

11 Veras RP, Mattos LC. Audiology and Aging: literature review and current horizons. Rev Bras Otorrinolaringol 2007;73(01):122-128

12 Samelli AG, Negretti CA, Ueda KS, Moreira RR, Schochat E. Comparação entre avaliação audiológica e screening: um estudo sobre presbiacusia. Rev Bras Otorrinolaringol 2011;77(01):70-76

13 Sousa CS, Castro Júnior Nd, Larsson EJ, Ching TH. Risk factors for presbycusis in a socio-economic middle-class sample. Rev Bras Otorrinolaringol (Engl Ed) 2009;75(04):530-536

14 Paiva KM, Cesar CLG, Alves MCGP, Barros MBA, Carandina L, Goldbaum M. Aging and self-reported hearing loss: a population-based study. Cad Saude Publica 2011;27(07):1292-1300 
15 Calais LL. Acuidade e sensibilidade auditiva no idoso [CD-ROM]. In: Anais do $20^{\circ}$ Encontro Internacional de Audiologia. 2005São Paulo, Brasil. São Paulo(SP): Academia Brasileira de Audiologia; 2005

16 Cruickshanks KJ, Wiley TL, Tweed TS, et al; The Epidemiology of Hearing Loss Study. Prevalence of hearing loss in older adults in Beaver Dam, Wisconsin. Am J Epidemiol 1998;148(09):879-886

17 Griz SMS, Menezes DC, Menezes PL. Audiometria Tonal e Logoaudiometria. Neto SC, Mello JF Jr, Martins RHG, Costa SS. Tratado de Otorrinolaringologia e Cirurgia Cervicofacial. Volume I Fundamentos. $2^{a}$ ed. São Paulo(SP): Roca; 2011:389-411

18 Yueh B, Shapiro N, MacLean CH, Shekelle PG. Screening and management of adult hearing loss in primary care: scientific review. JAMA 2003;289(15):1976-1985

19 Lopes AC. Audiometria Tonal Liminar. Bevilacqua MC, Martinez MAN, Balen SA, Pupo AC, Reis ACMB, Frota S. Tratado de Audiologia. $1^{a}$ ed. São Paulo(SP): Ed. Santos; 2012:63-80

20 Menegotto IH, Soldera CLC, Anderle P, Anhaia TC. Correlation between hearing loss and the results of the following questionnaires: Hearing Handicap Inventory for the Adults - Screening Version HHIA-S and Hearing Handicap Inventory for the Elderly - Screening Version - HHIE-S. Int Arch Otorhinolaryngol 2011; 15(03):319-326

21 Calviti KCFK, Pereira LD. Sensibilidade, especificidade e valores preditivos da queixa auditiva comparados com diferentes médias audiométricas. Braz J Otorhinolaryngol 2009;75(06):794-800

22 Valete-Rosalino CM, Rozenfeld S. Triagem auditiva em idosos: comparação entre auto-relato e audiometria. Rev Bras Otorrinolaringol 2005;71(02):193-200

23 Lopes AC, Nelli MP, Lauris JRP, Amorim RB, Melo ADP. Conditions of auditory health at work: inquiry of the auditory effects in workers exposed to occupational noise. Int Arch Otorhinolaryngol 2009;13(01):49-54

24 Davis A, Smith P, Ferguson M, Stephens D, Gianopoulos I. Acceptability, benefit and costs of early screening for hearing disability: a study of potential screening tests and models. Health Technol Assess 2007;11(42):1-294

25 Rosis ACA, Souza MRF, Iório MCM. Questionário Hearing Handicap Inventory for the Elderly - Screening version (HHIE-S): estudo da sensibilidade e especificidade. Rev Soc Bras Fonoaudiol. 2009; 14(03):339-345

26 Weinstein BE, Richards AM, Montano J. Handicap versus impairment: an important distinction. J Am Acad Audiol 1995;6(03):250-255

27 Romero J. Questionários de auto-avaliação de dificuldades auditivas: questões psicométricas na utilização clínica e em pesquisa [dissertação]. São Paulo (SP): Pontifícia Universidade Católica de São Paulo; 2003:71

28 Costa TRS. Distúrbios de audição e a classificação internacional de funcionalidade, incapacidade e saúde [tese]. São Paulo (SP): Pontifícia Universidade Católica de São Paulo; 2013:111

29 Corrêa GF, Russo ICP. Autopercepção do handicap em deficientes auditivos adultos e idosos. Rev CEFAC 1999;10(01):54-63 Available at: http://www.cefac.br/revista/revista11/Artigo\%207.pdf

30 Ventry IM, Weinstein BE. The hearing handicap inventory for the elderly: a new tool. Ear Hear 1982;3(03):128-134

31 Santiago LM, Novaes CO. Auto-avaliação da audição em idosos. Rev CEFAC 2009;11(Suppl 1):98-105

32 Marques ACDO, Kozlowski L, Marques JM. Reabilitação auditiva no idoso. Rev Bras Otorrinolaringol. 2004;70(06):806-811

33 Weinstein BE. Validity of a screening protocol for identifying elderly people with hearing problems. ASHA 1986;28(05):41-45

34 Weinstein BE, Ventry IM. Audiometric correlates of the Hearing Handicap Inventory for the elderly. J Speech Hear Disord 1983; 48(04):379-384

35 Lichtenstein MJ, Bess FH, Logan SA. Diagnostic performance of the hearing handicap inventory for the elderly (screening version) against differing definitions of hearing loss. Ear Hear 1988;9(04): 208-211
36 United States. Guidelines for the identification of hearing impairment/handicap in adult/elderly persons. ASHA 1989;31(08):59-63

37 Ventry IM, Weinstein BE. Identification of elderly people with hearing problems. ASHA 1983;25(07):37-42

38 Weinstein BE, Spitzer JB, Ventry IM. Test-retest reliability of the Hearing Handicap Inventory for the Elderly. Ear Hear 1986; 7(05): 295-299

39 Newman CW, Weinstein BE. Test-retest reliability of the Hearing Handicap Inventory for the Elderly using two administration approaches. Ear Hear 1989;10(03):190-191

40 Wieselberg MB. A auto-avaliação do handicap em idosos portadores de deficiência auditiva: o uso do H.H.I.E. [dissertação]. São Paulo (SP): Pontifícia Universidade Católica de São Paulo; 1997:108

41 de Paiva SM, Simões J, Paiva A, Newman C, Castro E Sousa F, Bébéar JP. Validity and Reliability of the Hearing Handicap Inventory for Elderly: Version Adapted for Use on the Portuguese Population. J Am Acad Audiol. 2016 Sep; 27(08):677-682

42 Cassol M, Ferreira MIDC, Poglia DMA. A utilização do questionário HHIE-S associado à avaliação audiológica e vocal num grupo de idosos. Estud Interdiscipl Envelhec. 2007;12(01):81-95

43 Sindhusake D, Mitchell P, Smith W, et al. Validation of selfreported hearing loss. The Blue Mountains Hearing Study. Int J Epidemiol 2001;30(06):1371-1378

44 Gopinath B, Hickson L, Schneider J, et al. Hearing-impaired adults are at increased risk of experiencing emotional distress and social engagement restrictions five years later. Age Ageing 2012;41(05): 618-623

45 Dalton DS, Cruickshanks KJ, Klein BEK, Klein R, Wiley TL, Nondahl DM. The impact of hearing loss on quality of life in older adults. Gerontologist 2003;43(05):661-668

46 Pugh KC, Crandell CC. Hearing loss, hearing handicap, and functional health status between African American and Caucasian American seniors. J Am Acad Audiol 2002;13(09):493-502

47 Mattos LC, Veras RP. A prevalência da perda auditiva em uma população de idosos da cidade do Rio de Janeiro: um estudo seccional. Rev Bras Otorrinolaringol 2007;73(05):654-659

48 Yamamoto $\mathrm{CH}$, Ferrari DV. Relação entre limiares audiométricos, handicap e tempo para procura de tratamento da deficiência auditiva. Rev Soc Bras Fonoaudiol. 2012;17(02):135-141

49 Jupiter T. Screening for hearing loss in the elderly using distortion product otoacoustic emissions, pure tones, and a self-assessment tool. Am J Audiol 2009;18(02):99-107

50 Gopinath B, Schneider J, Hickson L, et al. Hearing handicap, rather than measured hearing impairment, predicts poorer quality of life over 10 years in older adults. Maturitas 2012;72(02):146-151

51 Saito H, Nishiwaki Y, Michikawa T, et al. Hearing handicap predicts the development of depressive symptoms after 3 years in older community-dwelling Japanese. J Am Geriatr Soc 2010; 58(01):93-97

52 John AB, Kreisman BM, Pallett S. Validity of hearing impairment calculation methods for prediction of self-reported hearing handicap. Noise Health 2012;14(56):13-20

$53 \mathrm{Wu}$ HY, Chin JJ, Tong HMH. Screening for hearing impairment in a cohort of elderly patients attending a hospital geriatric medicine service. Singapore Med J 2004;45(02):79-84

54 Tomioka K, Ikeda H, Hanaie K, et al. The Hearing Handicap Inventory for Elderly-Screening (HHIE-S) versus a single question: reliability, validity, and relations with quality of life measures in the elderly community, Japan. Qual Life Res 2013;22(05):1151-1159

55 Chou R, Dana T, Bougatsos C, Fleming C, Beil T. Screening adults aged 50 years or older for hearing loss: a review of the evidence for the U.S. preventive services task force. Ann Intern Med 2011; 154(05):347-355

56 Chang HP, Ho CY, Chou P. The factors associated with a selfperceived hearing handicap in elderly people with hearing impairment-results from a community-based study. Ear Hear 2009; 30(05):576-583 
57 Russo ICP. Reabilitação Auditiva de Idosos. Bevilacqua MC, Martinez MAN, Balen SA, Pupo AC, Reis ACMB, Frota S. Tratado de Audiologia. $1^{\mathrm{a}}$ ed. São Paulo(SP): Ed. Santos; 2012:775-87

58 Freitas CDD, Costa MJ. Processo de adaptação de próteses auditivas em usuários atendidos em uma instituição pública federal parte II: resultados dos questionários de auto-avaliação. Rev Bras Otorrinolaringol 2007;73(05):660-670

59 Russo ICP, Pereira LD, Carvallo RMM, Anastásio ART. Encaminhamentos sobre a classificação do grau de perda auditiva em nossa realidade. Rev Soc Bras Fonoaudiol. 2009;14(02):287-288

60 World Health Organization (WHO). Prevention of blindness and deafness. Grades of hearing impairment [Internet]. Genebra: World Health Organization (WHO; 2016 [cited 2016 May 5] Available from: http://www.who.int/pbd/deafness/hearing_impairment_grades/en/

61 Lichtenstein MJ, Bess FH, Logan SA. Validation of screening tools for identifying hearing-impaired elderly in primary care. JAMA 1988;259(19):2875-2878

62 Pereira MG. Epidemiologia: Teoria e Prática. $1^{\mathfrak{a}}$ ed. Rio de Janeiro (RJ): Guanabara Koogan; 1995

63 Fletcher RM, Fletcher SW, Wagner EH. Clinical Epidemiology, the essentials. $1^{\text {st }}$ edition. Philadelphia: Lippincott Williams \& Wilkins; 1983

64 Sestrem E. Avaliação da auto-percepção do handicap auditivo em idosos e percepção da fala: um estudo comparativo [dissertação]. Curitiba (PR): Universidade Tuiuti do Paraná; 2000:127

65 Salonen J, Johansson R, Karjalainen S, Vahlberg T, Isoaho R Relationship between self-reported hearing and measured hear- ing impairment in an elderly population in Finland. Int J Audiol 2011;50(05):297-302

66 Wiley TL, Cruickshanks KJ, Nondahl DM, Tweed TS. Self-reported hearing handicap and audiometric measures in older adults. J Am Acad Audiol 2000;11(02):67-75

67 Chew HS, Yeak S. Quality of life in patients with untreated agerelated hearing loss. J Laryngol Otol 2010;124(08):835-841

68 Hands S. Hearing loss in over-65s: is routine questionnaire screening worthwhile? J Laryngol Otol 2000;114(09):661-666

69 Macedo LS, Pupo AC, Balieiro CR. Aplicabilidade dos Questionários de Auto-Avaliação em Adultos e Idosos com Deficiência Auditiva. Distúrb Comun 2006;18(01):19-25

70 Aiello CP, Lima II, Ferrari DV. Validity and reliability of the hearing handicap inventory for adults. Rev Bras Otorrinolaringol (Engl Ed) 2011;77(04):432-438

71 Deepthi R, Kasthuri A. Validation of the use of self-reported hearing loss and the Hearing Handicap Inventory for elderly among rural Indian elderly population. Arch Gerontol Geriatr 2012;55(03):762-767

72 Camargo MK. Percepção da desvantagem auditiva em idosos estudo da sensibilidade e especificidade do HHIE-S [monografia de conclusão do Curso de Especialização em Audiologia]. Porto Alegre (RS): Universidade Federal do Rio Grande do Sul; 2013:42

73 Tavares PF. Perda auditiva no idoso - suas interferências na vida psicossocial [monografia de conclusão do Curso de Especialização em Audiologia Clínica]. Itajaí (SC): Centro de Especialização em Fonoaudiologia Clínica; 2001:30 